\title{
THE DEVELOPMENT OF ENTREPRENEURS AT UNIVERSITY IN AN EMERGING ECONOMY: A CONCEPTUAL FRAMEWORK
}

\author{
Marlin Hoffman ${ }^{1}$
}

\begin{abstract}
:
A conceptual framework is developed to postulate the process of developing entrepreneurs at a university level as a panacea for mitigating high levels of graduate unemployment in South Africa. The challenges are compounded by slow economic growth and the resultant high unemployment levels. Despite the growing body of empirical research evidence on the development of entrepreneurs in general, there is limited research on the development of student entrepreneurship. Drawing on Azjen's (1991) theory of planned behaviour, the paper conceptualises on factors that potentially influence the intention of students within the university to become entrepreneurs. Following Azen (1991), the paper interrogates the influence of the following four factors, namely, attitude towards entrepreneurship, role models, entrepreneurial leaders, and resources and opportunities. The conceptual framework proposes a model that will assist in developing student entrepreneurship mindsets and aptitudes that will equip them to embark on rather starting their own ventures upon graduation, than seeking employment. The entrepreneurship development process will create opportunities for selfemployment, as well as employment creation within the South African economy.
\end{abstract}

\section{Introduction}

The end of the Apartheid system in 1994 heralded a non-racial 'rainbow nation' which is still beset by a deepseated 350-years legacy of the past. The system marginalised the black majority population and the effects of the marginalisation continues and cannot be corrected by single events (Hoffman, 2019). The dawn of democracy opened a new era for black businesses in South Africa, reinforced by laws and regulations that support the development, promotion and growth of black entrepreneurs. The National Development Plan 2030 (NDP, 2013) emphasises the development of entrepreneurial skills among the youth, to mitigate the unsustainable $27.6 \%$ unemployment rate (StatsSA, 2019). The national government policy imperatives prioritise growing the small business sector through equipping aspiring business owners with requisite entrepreneurial and related skill sets. There is need for systematic analysis of the underlying factors influencing student entrepreneurship within the university sector, before prescribing solutions and action plans. The paper seeks to contribute towards the identification of factors impacting on the development of student entrepreneurs in South Africa.

1University of the Western Cape; mjhoffman@uwc.ac.za 


\section{Background}

This section outlines some of the historical context that contributed to the marginalisation of the majority black population in participating in national developments as wealth creators.

\section{Entrepreneurship prior to colonialism}

Entrepreneurship has been practised since ancient times as communities engaged in various forms of barter trading. The Khoikhoi, descendants of the Khoisan, settled down from nomadic lifestyles and started farming close to fresh water supplies (Oliver and Oliver, 2017). Thus, hunting gave way to farming and breeding of livestock and members of the tribe acquired land which was either purchased from or given by the chief (Oliver and Oliver, 2017). Giliomee and Mbenga (2007) state that the Khoisan acquired livestock from groups living in Botswana. Trading of livestock gained momentum as tribes and communities exchanged with others who specialised in making tools from iron and copper. Venter et al. (2015) stated that despite the socialist economy within the early African society, accumulating wealth and success were highly valued accomplishments. Verhoef (2015) notes that early African entrepreneurs were traders, acting as middlemen by sourcing various commodities for exchange with European sailors who passed through the Cape. As early as the 1590s the locals traded copper, iron and tobacco (Giliomee and Mbenga,2007) with European mariners who sailed to and from the East (Oliver and Oliver, 2017). This lasted for centuries until the Europeans arrived to stay in the 16th century.

\section{Effects of colonialism}

The arrival of the Dutch in 1652 in the Cape region, led to the forced displacement of the indigenous population promulgation and the enforcement of unjust and repressive laws. Worden (1994) traces the origins of racism in South Africa to the expansion of European colonialism in Africa, dispossessing the indigenous people of their land and rights. Giliomee and Mbenga (2007) infer that the colonisers brought along Western culture and Western intellectual baggage to Africa. Bundy (1979) points out that the bartering trade activities came to an end after the introduction of the 'formal' economy. The banning of informal barter trading (a form of self-employment for indigenous population) that had existed prior to the arrival of the white people, led to loss of 'income' and de facto 'unemployment'. This led to African entrepreneurs seeking opportunities in the 'informal sector' (Austen, 1987). Verhoef (2015) stated that lack of education and training, coupled with lack of financial resources which were embedded in colonial legislation, became barriers for indigenous entrepreneurs. For instance, the oppressive legislation introduced colonial taxation in the Cape Colony in 1894, which taxed freehold labour (Verhoef, 2015). The economic and political oppression continued and deepened when the colonial government gave way to the Afrikaner National Government (Hoffman, 2019).

\section{Effects of Apartheid}

The Nationalist Government came to power in 1948 and enforced racial discrimination and segregation through various laws, which were called apartheid (Kopel, 2012). Worden (2000) points out that the colonial laws were instituted as a legal principle that underpinned a theory that whites should be treated more favourably than blacks. Mahlauli et al. (2015) highlight that apartheid not only implemented a system of racial discrimination and segregation, but also extended the system to all spheres of economic and social life in government, labour and markets, and residential areas.

Reddy (2004) reported that when the Nationalist government came to power, the percentage of black students enrolled at university was $4.8 \%$. Education became an oppressive tool enforced through legislation to offer inferior education to the majority. Van Gensen (2005) noted that government introduced a new interventionist system in the state and civil service, based on colonial educational standards. The quality of subjects taught at the various levels of education to the various racial groups, was differentiated into state-controlled and maintained an education policy designed to ill-equip non-white learners (Jansen, 2002).

Discrimination was amplified in all spheres of social, economic and political systems, compounded by the relocation of blacks to 'homelands', comprising geographically distant, agriculturally barren and economically destitute areas (Kopel, 2012). The black businessmen and women lost their businesses through the oppressive displacement and dispossession of their ancestral land. The majority of the population was located in areas that lacked basic 
infrastructure and markets. Motsueyane (1989) stated that there were more than 500 laws that impeded the involvement of the black community from participating in the economy as owners and managers. The repressive laws curtailed any meaningful participation of the majority in the national economic sector, and they were rendered jobless in the homelands alluded to above. This led to people of all age groups leaving the homelands to seek employment in the mining towns. They left behind mothers and children who had to fend for themselves during these long periods of absence of the fathers and sons. Co (2003) points out one of the effects of loss of status as 'retreatism', which is characterised by the psychological repression of trauma associated with a loss of status, as these men and boys were subjected to work in terrible conditions, which resulted in the repressed trauma needing an outlet. The outlet was in the form of unhappiness and violence, and in this case, political violence, which contributed to the government of the day reviewing its economic and political policies, which ultimately led to democracy in 1994.

\section{Entrepreneurship and black business in democracy}

The dawn of the democracy in 1994 brought a new era of rebuilding and rectifying the injustices of the past. Apartheid-era laws were repealed and new laws promulgated in line with the economic and political dispensation. Equally the development of small businesses was prioritised in the 1995 White Paper, presented to Parliament by Trevor Manuel, at that time the minister of the Trade and Industry. The main thrust of the policy was broadening of economic participation by all citizens and those previously marginalised (Kruger, 2011). In turn, the White Paper culminated in the promulgation of the Small Business Act of 1996, which was subsequently amended into its current form. In essence, the Small Business Act called for the establishment of agencies supportive of small business development, such as the Small Enterprise Development Agency (SEDA) in 2004 and the Small Enterprise Finance Agency (SEFA) in 2012.

The small and medium enterprises (SMEs) sector is considered to be the engine of economic growth and poverty eradication (Katua, 2014). South Africa like other countries in the world, has recognised the critical role of the SME sector towards broadening participation of formerly excluded people, as well as a source of new jobs and employment. However, Bushe (2019) notes that $40 \%$ of all new businesses fail in the first year, $60 \%$ in their second year and $90 \%$ of new businesses fail within the first 10 years of their life cycle. There is an accumulating body of empirical research evidence on the failure of small businesses in South Africa (eg., Bushe, 2019; Leboea, 2017; Rungain and Potgieter, 2018). The studies cite different factors in explaining the high attrition rates of small businesses. The next section offers a conceptual framework that sheds light on some of the tentative solutions through the development of student entrepreneurship.

\section{Conceptual Framework}

The propositions based on the theory of planned behaviour, follow previous studies (e.g. Malebana, 2014 and Gird and Bagram, 2008) that explored factors influencing entrepreneurial intention. Azjen (1991) postulated that an intention is the precursor to behaviour and that if the intention can be influenced, the subsequent behaviour will be influenced as well. The conceptual framework focuses on students studying entrepreneurship at the higher education institutions, and how the entrepreneurial intention of these students can be nurtured. Four factors are considered in the framework to better understand the elements or factors that influence entrepreneurial intention (See Figure1):

a) Attitude towards entrepreneurship,

b) Entrepreneurial leaders,

c) Role models, and

d) Resources and opportunities at universities.

An overview of the South African economy will be presented to highlight the context and the significance of entrepreneurs and small businesses in the country. 


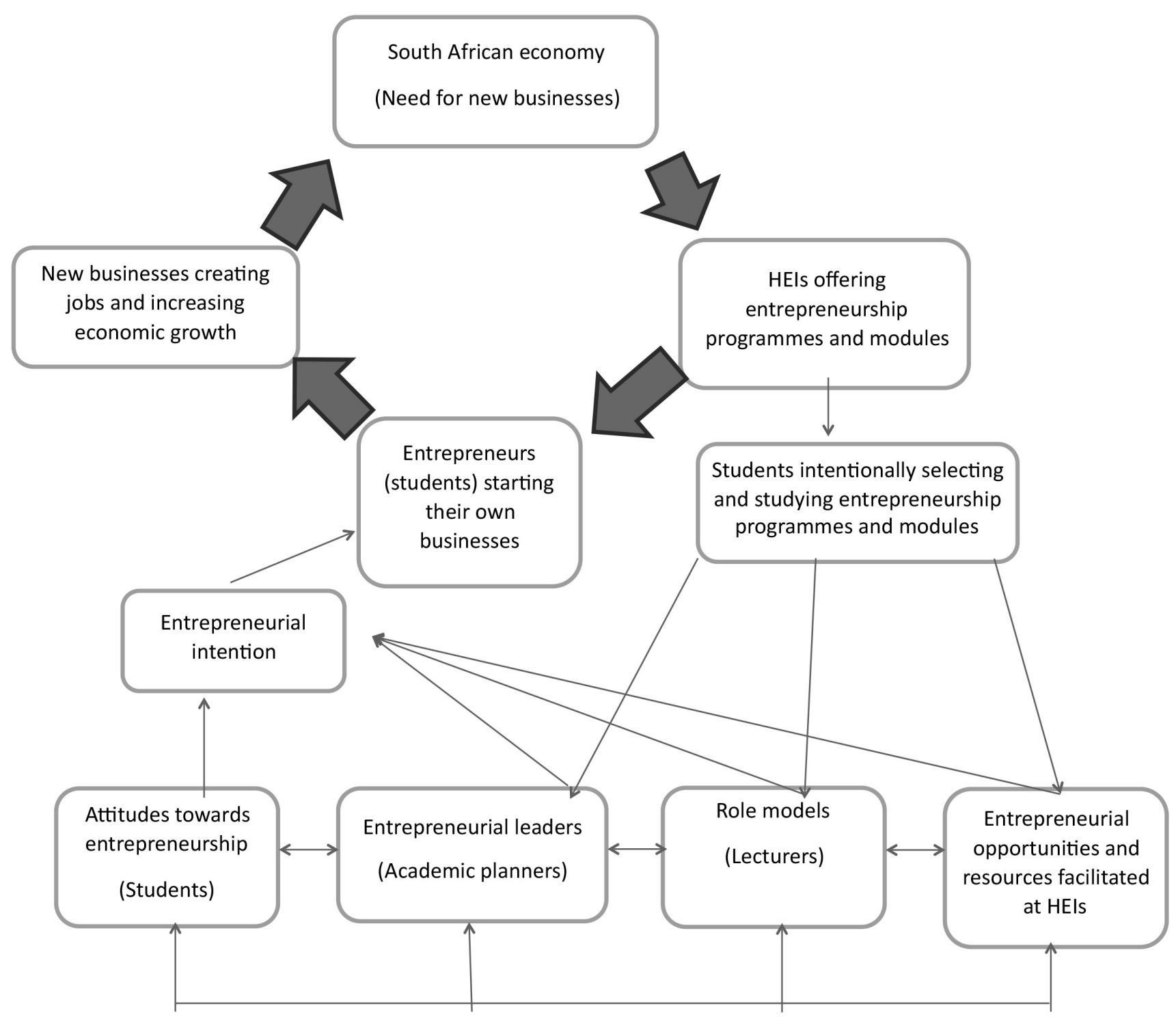

Figure 1: Conceptual framework of the study (Hoffman, 2019)

\section{The South African economy}

The economy has continued to experience slow to low economic growth rates since the dawn of the democratic government in 1994. By 2019 the unemployment rate was $27.6 \%$ out of a working population of 22.5 million citizens. In practical terms 16.3 million people are employed within the formal, informal, agricultural, and private household sectors, while 6.2 million are unemployed, and 15.8 million are economically inactive (StatsSA, 2019). The unemployment problem has led to the formulation of the National Development Plan 2030 (NDP 2030) (2013) that is projected to have created 11 million jobs in the year 2030. The government has also launched a number of initiatives to enhance the growth of the economy and to create jobs. The NDP 2030 identifies entrepreneurship as the vehicle for alleviating unemployment through sustainable national economic growth going forward.

\section{Higher Education Institution Curriculum}

Entrepreneurship education is vital to the success of future entrepreneurs and it is important that higher education institutions remain up to date with the entrepreneurship education curriculum (Hoffman, 2019). The growing number of entrepreneurship modules offered by universities, reflect the recognition that entrepreneurship education is 
directly related to entrepreneurial outcomes (Nabi and Linan, 2011; Rideout and Gray, 2013). This understanding stems from the belief that education is the best way to provide students with the skills and knowledge to prosper in the world of labour (Adcroft, Dhaliwal and Wills, 2005; Kirby, 2003). Linan (2007) added that developing opportunityrecognition capacities and related skills through creativity, will enhance the probability of a person becoming an entrepreneur and developing favourable personal attitudes towards entrepreneurship.

Studies have shown that entrepreneurship education and training can influence the behaviour and future attitude of students (Fayolle et al., 2006). The proposition that the development of a sound entrepreneurial culture stabilises economies and creates growth opportunities, is based on historical economic fluctuations and has convinced stakeholders, including education institutions. Tijssen (2006) states that empirical evidence points to universities as the breeding ground for fostering the entrepreneurial spirit and culture. Nicolaides (2011) noted the strong relationship between education level and entrepreneurial activity and the significance thereof on the success or failure of new business ventures. Universities alsl over the world are offering entrepreneurship programmes, which are driven by two factors, namely the demand from society, and the growing number of students wanting to become entrepreneurs (Postigo, 2002). Hatten and Ruhland (1995) studied the effects of entrepreneurship programs on students' attitude towards entrepreneurship, and concluded that the latter can be measured and changed. This is supported by Ede, et al. (1998); Robinson, et al. (1991) and Wang and Wong, 2004. In many ways the literature strongly confirms the role of institutions of higher education in offering entrepreneurship education to enhance economic development in countries such as South Africa.

As alluded in earlier sections, this conceptual paper draws on Azjen's (1991) Theory of Planned Behaviour to examine the relationship between factors that influence entrepreneurial intention and entrepreneurial behaviour. The conceptual relationships between the four factors are shown in Figure 1 above.

\section{Attitudes towards entrepreneurship}

An attitude refers to the degree that a person holds or evaluates a particular behaviour, be it positive or negative (Azjen (1988), Fishbein and Azjen,1975). Azjen (2002) further elaborates that beliefs about the likely outcome of a behaviour and the evaluation of those outcomes are behavioural beliefs which affect the attitude towards a behaviour. From this perspective, the first encounter that a student would have with entrepreneurship as a subject or module, could be a determinant of how the student views entrepreneurship. This will have an impact on the student's entrepreneurial intention and eventually the student's entrepreneurial behaviour. It is therefore important that this exposure to the subject matter should be done by experienced facilitators in terms of teaching the subject matter and practice. It is therefore imperative that the subject matter be presented with positive outcomes as well as the pitfalls for the entrepreneur. The proposition is that there should be a balance between practical experience and teaching competence when selecting entrepreneurship lecturers and facilitators.

\section{Entrepreneurial Leadership}

The conceptual development of entrepreneurial leadership has evolved from different components and it embraces the context and climate of the leader (Hoffman, 2019). The definition of entrepreneurial leadership has evolved, since it was first conceptualised by Cummingham and Lischeron (1991). To date the definition has gone through many changes or adaptations as researchers grappled with the concept (see McGrath and McMillan 2000; Ireland et al. 2003; Gupta et al., 2004). This proposition follows Renko et al. (2015), who define entrepreneurial leadership as a process that involves influencing and directing the performance of a group of members towards the achievement of organisational goals to recognise and exploit entrepreneurial opportunities. This two-pronged approach identifies the role of entrepreneurship education pedagogy and the process of guiding students in the right direction during the idea-development phase. The responsibility of an entrepreneurial leader is to identify opportunities in the market and university environment, and to exploit the opportunities to the benefit of the team. The emphasis of the entrepreneurial leadership development process is to rather nurture the desire for entrepreneurship than teaching students about entrepreneurship. Postigo and Tamborini (2002) emphasise that education about entrepreneurship is mainly based on constructs and transference of knowledge, whereas education for entrepreneurship focuses on the learning experiences and the development of competencies, skills, aptitudes and values. From this perspective, universities' curricula should move toward teaching for entrepreneurship and use the know-how approach to equip students in becoming successful entrepreneurs (Hoffman, 2019). Entrepreneurial leaders responsible for entrepreneurship programmes will therefore have an impact on harnessing the students' entrepreneurial intention. 


\section{Role Models}

There are as many descriptions and definitions as there are authors of role models. A common thread through the various definitions is an individual that can inspire and motivate others to make certain decisions to obtain certain goals (Basow and Howe, 1980; Shapiro, Haseline and Rowe, 1978; Wright, Wong and Newill, 1997). Role models provide the necessary proof that goals can be achieved, and this increases the desire to strive for a particular position or condition (Hoffman, 2019). They also demonstrate that skills and motivation contribute to the achievement of goals (Weber et al., 2013). Therefore, role models encourage the drive for others to become entrepreneurs and make entrepreneurial ambitions a reality (Arenius and De Clerq, 2005; Koelliger et al., 2007 and Mueller, 2006). Scherer et al. (1989) stated that empirical evidence shows that 35-70\% of entrepreneurs have entrepreneurial role models. Nauta and Kakaly (2001) point out that increasing numbers of entrepreneurs report the support and advice provided by the role models that are similar to a mentor-mentee relationship. A growing body of empirical evidence support the positive relationship between role models and the entrepreneurial intention of students (Krueger et al., 2000; Scherer et al., 1989, Van Auken et al., 2006a and 2006b). Role models change the attitudes and beliefs about the person's self or perceived ability to be successful in a new venture (Bosman et al., 2012; Van Auken et al., 2006b).

Role models provide evidence to students that it is possible to make a success of starting a new venture. Some of the reasons that there are a few entrepreneurial role models, include the apartheid legacy discussed above. The best place to look for role models, based on the experience in industry and academia, would be at universities. Considering that the higher education institution would be teaching for entrepreneurship, an element of experience should be present. The lecturer or facilitator of an entrepreneurship program would be the proxy for a role model to students - guiding the student towards identifying and exploiting opportunities for entrepreneurial start-ups.

\section{Entrepreneurial Resources and Opportunities}

Few studies focus on how contextual and situational factors within the university environment influence the development and nurturing of the entrepreneurial intention (Trivedi, 2016). University support mechanisms influence entrepreneurial activities (Fini et al., 2009) and the support is important in shaping students' perception of entrepreneurship and attitude towards entrepreneurship (Johannisso, 1991 and Autio et al., 1997). One of the major functions of the universities and teaching institutions should be to build entrepreneurial awareness and develop students' entrepreneurial skills (Hoffman, 2019). Trivedi (2016) points out that the support should thus shift from traditional teaching roles providing cognitive and non-cognitive support on venture creation. Therefore, the university has to move from a traditional knowledge- generation institution to a living entrepreneurial ecosystem, that enhances the concept of an entrepreneurial university (Hoffman, 2019). The importance of entrepreneurial universities is vital to the training and development of students' entrepreneurial skills and in nurturing entrepreneurial intention among students.

\section{Conclusion}

The need for entrepreneurs in South Africa has reached critical levels. This is recognised and prioritised by the NDP 2030, that focuses on creating 11 million jobs by 2030. Entrepreneurs are key to the delivery of the national economic development goals. Therefore, there is need for tertiary institutions to refocus their objective towards the training and development of student entrepreneurs. This conceptual paper has identified factors adapted from Azjen's (1991) Theory of Planned Behaviour (1991), to rather refocus entrepreneurship curricula in universities towards nurturing the desire for entrepreneurship, than to teach students about entrepreneurship. The conceptual framework suggests four factors that need to be addressed to develop entrepreneurial intention that influences entrepreneurial behaviour. Attitude towards entrepreneurship is determined by the student's encounter and experience with entrepreneurship and the manner in which entrepreneurship as a concept is introduced to the student, therefore attitude towards entrepreneurship can be positive or negative. The second factor identifies the importance of entrepreneurial leaders with requisite know-how and academic experience in developing student entrepreneurs. Role models are important in the development of students as they can also take on a mentormentee role to guide the student in achieving their goals and dreams. Opportunities and resources at university play an important role in the development of entrepreneurs, as the support creates a conducive environment and ecosystem that encourages growth and development of students and future entrepreneurs. 
Therefore, the conceptual model envisages universities as custodians of entrepreneurship, education and future entrepreneurs that would contribute towards national economic development.

Recommendation for future research

The conceptual framework proposes an approach towards the development and training of future entrepreneurs in South Africa. The aim is to assist universities and policymakers in this training. The conceptual framework contributes to our understanding of the development of student entrepreneurs. Future research should empirically test the efficacy of the model and build on it, to develop a robust approach towards the development of student entrepreneurs in South Africa and beyond.

\section{References}

Adcroft, A.; Dhaliwal, S. and Willis, R. 2005. Insatiable demand or academic supply: The intellectual context of entrepreneurship education. European Business Review, 17(6): 518-531.

Ajzen, I. 1988. Attitudes, personality, and behavior. Chicago: Dorsey Press.

Ajzen, I. 1991. The theory of planned behaviour. Organisational Behaviour and Human Decision Processes, 50: 179211.

Arenius, P. and De Clerq, D. 2005. A network-based approach on opportunity recognition. Small Business Economics, 24: $249-265$.

Austen R. A. 1987. African economic history: internal development and external dependency. London: J. Currey.

Basow, S. and Howe, K. 1980. Role-model influence: Effects of sex and sex-role attitude in college students. Psychology of Women Quarterly, 4: 558-572.

Bosman, N.; Hessels, J.; Schutjens, V.; Van Praag, M. and Verheul, I. 2012. Entrepreneurship and role models. Journal of Economic Psychology, 33: 410-424.

Bundy, C 1979. The rise and fall of the South African peasantry. London: Heinemann.

Busher, B. (2019). The causes and impact of business failure among small to micro and medium enterprises in South Africa. African Public Service Delivery and Performance Review 7(1), a210 https://doi.org/10.4102/apsdpr.v7i.210

Co, M.J. 2003. A socio-cultural explanation of black entrepreneurship in South Africa. South African Journal of Business Management, 34(4): 35-43.

Cunningham, J.B. and Lischeron, J. 1991. Defining entrepreneurship. Journal of Small Business Management, 29(1): 45-62.

Ede, F.O.; Panigrahi, B. and Calcich, S.E. 1998. African American students' attitude towards entrepreneurship education. Journal of Education for Business, 73(5): 291-307.

Fayolle, A.; Gailly, B. and Lassas-Clerc, N. 2006. Assessing the impact of entrepreneurship education programmes: A new methodology. Journal of European Industrial Training, 30(9): 701-720.

Fini, R.; Grimaldi, R.; Marzocchi, G.L. and Sobrero, M. 2009. The foundation of entrepreneurial intention. Paper presented at the Summer Conference, Denmark, 17-19 June.

Fishbein, M. and Ajzen, I. 1975. Belief, attitude, intention and behaviour: An introduction of theory and research. Boston, MA: Addison-Wesley.

Giliomee, H. and Mbenga, B. 2007. New history of South Africa. Tafelberg, Cape Town.

Gird, A. and Bagraim, J. 2008. The theory of planned behaviour as a predictor of entrepreneurial intent among finalyear university students. South African Journal of Psychology, 38(4): 711-724.

Gupta, V.; McMillan, I.C. and Surie, G. 2004. Entrepreneurial leadership: Developing and measuring a cross-cultural construct. Journal of Business Venturing, 19(2): 241-260.

Hatten, T. and Ruhland, S. 1995. Student attitude toward entrepreneurship as predicted by participation in an SBI program. Journal of Education Business, 70(4): 224-228. 
Hoffman, M.J. (2019). Commerce Faculties: A hidden pipeline of entrepreneurs, a model of entrepreneurial intention. Doctoral Thesis. Bellville: University of the Western Cape.

Ireland, R.D.; Hitt, M.A. and Simon, D.G. 2003. A model for strategic entrepreneurship: The construct and its dimensions. Journal of Management, 29(6): 963.

Jansen, J.D. 2002. Mergers in higher education: lessons learned in transitional contexts. Pretoria. UNISA Press.

Johannisson, B. 1991. University training for entrepreneurship: A Swedish approach. Entrepreneurship and Regional Development, 3(1): 67-82.

Katua, N.T. 2014. The role of SMEs in employment creation and economic growth in selected countries. International Journal of Education and Research, 2(2): 461-472.

Kirby, D. 2003. Entrepreneurship. London: McGraw-Hill.

Koellinger, P.; Minniti, M. and Schade, C. 2007. I think I can: Overconfidence and entrepreneurial behaviour. Journal of Economic Psychology, 28: 110-132.

Kopel, S. 2012, Guide to business law - commercial law. (5th Edition). Cape Town: Oxford University Press Southern Africa.

Kraaijenbrink, J.; Bos, G. and Groen, A. 2010. What do students think of entrepreneurial support given by their universities? International Journal of Entrepreneurship and Small Business, 9(1): 110-125.

Krueger, N.F.; Reilly, M. and Carsrud, A.L. 2000. Competing models of entrepreneurial intentions. Journal of Business Venturing, 15: 411-432.

Kruger, L.P. 2011. The impact of black economic empowerment (BEE) on South African businesses: Focusing on ten dimensions of business performance. Southern African Business Review, 15(3): 207-233.

Leboea, S.T. (2017). The factors influencing SME failure in South Africa. Masters Dissertation. Graduate School of Business, UCT, South Africa.

Linán, F. 2007. The role of entrepreneurship education in the entrepreneurial process. In: A. Fayolle (Ed.). Handbook of research in entrepreneurship education. Cheltenham, UK: Edward Elgar Publishing.

Malebana, J. (2014). Entrepreneurial Intention of South African rural university students: A test of the theory of planned behaviour. Journal of Economics and Behavioural Studies. Vol. 6 No.2 pp. 130 - 143.

Motsuenyane, A. 1989. The development of black entrepreneurship in South Africa. Lagos: Nigerian Institute of International Affairs.

Mueller, P. 2006. Entrepreneurship in the region: Breeding ground for nascent entrepreneurs? Small Business Economics, 27: 41-58.

Nabi, G. and Linán, F. 2011. Graduate entrepreneurship in the developing world: Intentions, education and development. Education and Training, 53(3): 325-334.

Nafukho, F.M. and Muyia, M.A.H. 2010. Entrepreneurship and socioeconomic development in Africa: A reality or myth? Journal of Industrial Training, 34(2): 96-109.

Nicolaides, A. 2011. Entrepreneurship - the role of higher education in South Africa. Educational Research, 2(4): 1043-1050.

Oliver, E. and Oliver, W. 2017. The colonisation of South Africa: A unique case. HTS Theological Studies 73(3).

Postigo, S. and Tamborini, M.F. 2002. Entrepreneurship education in Argentina: The case of San Andres University. Paper presented at the Internationalizing Entrepreneurship Education and Training Conference - IntEnt 2002, Malaysia, July 2002.

Reddy, T. 2004. Higher education and social transformation: South Africa case study - Council of Higher Education. [Online]. Available at: www.che.ac.za [Accessed: 4 January 2017].

Renko, M.; El Tarabishy, A.; Carsrud, A.L. and Brännback, M. 2015. Understanding and measuring entrepreneurial leadership. Journal of Small Business Management, 53(1): 54-74. 
Rideout, E.C. and Gray, D.O. 2013. Does entrepreneurship education really work? A review and methodological critique of the empirical literature on the effects of university-based entrepreneurship education. Journal of Small Business Management, 51(3): 329-351.

Robinson, P.B.; Stimpson, D.V.; Huefner, J.C. and Hunt, H.K. 1991. An attitude approach to the prediction of entrepreneurship. Entrepreneurship Theory and Practice, 15(4): 13-30.

Rungain, E.C. and Potgieter, M. (2018). The impact of financial support on the success of small, medium and micro enterprises in the Eastern Cape Province, Acta Commercii 18(1) https://doi.org/10.4102/ac.v18i.591

Scherer, R.; Adams, J.; Carley, S. and Wiebe, F. 1989. Role model performance effects on development of entrepreneurial career preferences. Entrepreneurship Theory and Practice, 13(3): 53-71.

Shapiro, E.; Haseltine, F. and Rowe, M. 1978. Moving up: Role models, mentors, and the 'patron system'. Sloan Management Review, 6(1): 19-47.

Tijssen, R.J.W. 2006. Universities and industrially relevant science: Toward measurement models and indicators of entrepreneurial orientation. Research Policy, 35(10): 269-280.

Trivedi, R. 2016. Does university play a significant role in shaping entrepreneurial intention? A cross-country comparative analysis. Journal for Small Business and Enterprise Development, 23(3): 790-811.

Van Auken, H.; Stephens, P.; Fry, F.L. and Silva, J. 2006a. Role model influences on entrepreneurial intentions: A comparison between USA and Mexico. International Entrepreneurship and Management Journal, 2(3): 325-336.

Van Auken, H.; Stephens, P.; Fry, F.L. and Silva, J. 2006b. The influence of role models on entrepreneurial intentions. Journal of Developmental Entrepreneurship, 11(2): 157-167.

Van Gensen, G. 2005. A model for branding practices in a new South Africa higher education landscape. Doctoral Thesis. Bloemfontein: Central University of Technology.

Venter, R.; Urban, B.; Beder, L.; Oosthuizen, C.; Reddy, C. and Venter, E. 2015. Entrepreneurship: Theory in practice. (3rd Edition). Cape Town: Oxford University Press Southern Africa.

Verhoef, G. 2015. The opportunity of inequality: African entrepreneurship and inequality. [Online]. Available at: file:///C:/Users/Admin/Downloads/essa_3202.pdf [Accessed: 16 November 2016].

Wang, C.K. and Wong, P.K. 2004. Entrepreneurial interest of university students in Singapore. Technovation, 24(2): 163-172.

Worden, N. 1994. The making of a modern South Africa: Conquest segregation and apartheid. Cambridge: Blackwell Publishers Wright, S.; Wong, A. and Newill, C. 1997. The impact of role models on medical students. Journal of General Internal Medicine, 12: 53-56.

Wright, S.; Wong, A. and Newill, C. 1997. The impact of role models on medical students. Journal of General Internal Medicine, 12: 53-56. 